\title{
Synthesis, characterization, and evaluation of some acyclic $S$-nucleosides of pyrazolo[3,4-d]pyrimidine-thiones as corrosion inhibitors for carbon steel in hydrochloric acid
}

\author{
R.S. Abdel Hameed ${ }^{1,2 *}$ and A.H. Shamroukh ${ }^{2,3}$ \\ ${ }^{1}$ Chemistry Department, Faculty of Science, Al-Azhar University, 11884, Cairo, Egypt \\ ${ }^{2}$ Chemistry Department, Faculty of Science, Hail University, Hail 1560, KSA \\ ${ }^{3}$ Photochemistry Department, National Research Centre, Dokki, 12622, Giza, Egypt \\ E-mail: mredars2@yahoo.com
}

\begin{abstract}
3-Methyl-1-phenyl-1,5-dihydro-pyrazolo[3,4- $d]$ pyrimidine-4-thione was prepared and used as a key compound for the preparation of some $S$-acyclic nucleosides of pyrazolo[3,4d]pyrimidine-thiones. Furthermore, the corrosion inhibitions of the prepared compounds towards carbon steel corrosion by $1.0 \mathrm{M}$ hydrochloric acid were evaluated by chemical and electrochemical methods. The effect of inhibitors concentrations and temperatures were studied. The corrosion inhibition efficiency increased with concentrations and decreased with temperature. Addition of inhibitor molecules to the aggressive medium produces a negative shift in the open circuit potential. Galvanostatic polarization measurements reveal that thione compounds act as mixed type inhibitors. Thermodynamic activation parameters were calculated and discussed. The results were in good agreement to each other.
\end{abstract}

Keywords: acyclic S-nucleosides, corrosion; inhibition; galvanostatic; thermodynamics.

Received: March 3, 2017. Revised: May 17, 2017. Published: July 10, $2017 . \quad$ doi: 10.17675/2305-6894$\underline{2017-6-3-8}$

\section{Introduction}

Corrosion is an afflicting problem associated with every use of metals. The use of organic inhibitors is one of the most practical and environmentally-friendly methods to protect metals and alloys against corrosion, A number of heterocyclic organic compounds having either a delocalized set of electrons or just an electron pair on nitrogen, oxygen or sulfur heteroatoms, through which they adsorb on metallic surfaces, can block the active sites to decrease the rate of corrosion of steel. The binding of pyrazolopyrimidine with acyclic and cyclic sugar moiety forming the corresponding nucleosides has commanded the worldwide attention of many research groups because of their pharmacological activities, especially as potential antiviral, [1] anticancer, [2] and antibiotic agents [3]. In connection of our research program for synthesis of different cyclic and acyclic nucleosides of fused heterocyclic with biological interest [4-7]. A large number of scientific studies have been 
devoted to the subject of corrosion inhibition of steel in acidic media [8-20] by heterocyclic compounds. Pyrazolo pyrimidinone derivatives are promising corrosion inhibitors as its contain functional groups, nitrogen and oxygen atoms in its structure which help the adsorption of the inhibitors on the steel surface, pyrazolo pyrimidinone derivatives of higher aqueous solubility and easily prepared from pyrazolo pyrimidine itself. From the literatures the use of pyrazolo pyrimidinone as corrosion inhibitors for steel are limited. Pyrazolo pyrimidinone compounds also have some medical applications due to no toxicity of it so it can be used as potential non-toxic corrosion inhibitors. In the previous work [8] pyrazolopyrimidine derivatives (3-(3-methyl-1-phenyl-1H-pyrazolo[3,4- $d]$ pyrimidin-4yloxy)-propionamide) were synthesized, characterized, and evaluated as corrosion inhibitors for steel in hydrochloric acid. This work aimed to synthesize and characterize new pyrazolopyrimidine derivatives with acyclic $S$-nucleosides to investigate their behavior as new inhibitors for the corrosion of steel in $1.0 \mathrm{M}$ hydrochloric acid corrosive medium. Effect of inhibitors concentrations and temperature are studied by chemical and electrochemical techniques. Thermodynamic activation parameters were calculated and discussed.

\section{Experimental}

\subsection{Synthesis}

All melting points are uncorrected and were measured using an Electrothermal IA 9100 apparatus, Shimadzu (Japan). Microanalytical data were performed by Vario El-Mentar apparatus, Organic Microanalysis Section, National Research Centre, Cairo, Egypt. Their results were found to be in agreement with the calculated values $( \pm 0.3)$. The IR spectra $(\mathrm{KBr})$ were recorded on a Perkin-Elmer 1650 spectrophotometer, National Research Centre, Cairo, Egypt. ${ }^{1} \mathrm{H}$ and ${ }^{13} \mathrm{C}$ NMR spectra were determined on a Jeol $300 \mathrm{MHz}$ in DMSO- $\mathrm{d}_{6}$, National Research Centre, and the chemical shifts were expressed in ppm relative to TMS as internal reference. Mass spectra were recorded on $70 \mathrm{eV}$ EI Ms-QP 1000 EX (Shimadzu, Japan), National Research Centre, Cairo, Egypt. Column chromatography was performed on (Merck) Silica gel 60 (particle size $0.06-0.2 \mathrm{~mm}$ ). Compound 1 (see Section 3.1) was prepared according to reported methods [8].

\section{3-Methyl-1-phenyl-1,5-dihydro-pyrazolo[3,4-d]pyrimidine-4-thione (2)}

A solution of compound 1 ( $0.226 \mathrm{~g}, 1 \mathrm{mmol})$ and phosphorus pentasulfide $(0.222 \mathrm{~g}, 1 \mathrm{mmol})$ in dry pyridine was refluxed for $1.5 \mathrm{~h}$. The reaction mixture was cooled and poured into ice water $(100 \mathrm{~mL})$ filtered off and acidified the filtrate with hydrochloric acid $(3 \mathrm{~mL}, 10 \%)$. The precipitated material was filtered off, washed with water, dried, and recrystallized from dioxane to give compound 2 . Yield $94 \%, \mathrm{mp} .280-282^{\circ} \mathrm{C}, \mathrm{IR}\left(\mathrm{KBr}, v, \mathrm{~cm}^{-1}\right): 3443$ $(\mathrm{NH})$ and $1346(\mathrm{C}=\mathrm{S}) .{ }^{1} \mathrm{H}$ NMR $\left(\mathrm{DMSO}_{-} \mathrm{d}_{6}, \delta \mathrm{ppm}\right): 2.69\left(\mathrm{~s}, 3 \mathrm{H}, \mathrm{CH}_{3}\right), 7.26-7.48(\mathrm{~m}, 5 \mathrm{H}$, Ar-H), 8.51 (s, 1H, H6-pyrimidine), 14.50 (s, 1H, NH, $\mathrm{D}_{2} \mathrm{O}$ exchangeable); ${ }^{13} \mathrm{C}$ NMR $\left(\mathrm{DMSO}_{6}, \delta \mathrm{ppm}\right): 9.40\left(\mathrm{CH}_{3}\right), 110.15(\mathrm{C} 3 \mathrm{a}), 120.29-138.86$ (6Ar-C), 139.70 (C7a), 
151.25 (C3), 160.90 (C6), 180.52 (CS); MS m/z (\%): $242\left[\mathrm{M}^{+}\right]$(100). Anal. calcd. for $\mathrm{C}_{12} \mathrm{H}_{10} \mathrm{~N}_{4} \mathrm{~S}$ (242.30): C, 59.48; H, 4.16; N, 23.12; S, 13.23. Found: C, 59.45; H, 4.14; N, $23.15 ; \mathrm{S}, 13.25$.

\section{4-Ethylsulfanyl-3-methyl-1-phenyl-1H-pyrazolo[3,4-d]pyrimidine (3)}

A solution of compound $2(0.24 \mathrm{~g}, 1 \mathrm{mmol})$ and sodium hydroxide $(0.04 \mathrm{~g}, 1 \mathrm{mmol})$ in ethanol $(50 \mathrm{~mL})$ was treated with ethyl iodide $(0.16 \mathrm{~mL}, 1 \mathrm{mmol})$ and the reaction mixture was warmed on a steam bath at $70^{\circ} \mathrm{C}$ for $2 \mathrm{~h}$. The formed precipitate was filtered off, dried, and recrystallized from dioxane to give compound 3. Yield $86 \%, \mathrm{mp} .215-217^{\circ} \mathrm{C}$, IR showed absence of the NH group. ${ }^{1} \mathrm{H}$ NMR $\left(\mathrm{DMSO}^{-\mathrm{d}_{6}}, \delta \mathrm{ppm}\right): 1.39(\mathrm{t}, J=7.5 \mathrm{~Hz}, 3 \mathrm{H}$, $\left.\mathrm{SCH}_{2} \mathrm{CH}_{3}\right), 2.42\left(\mathrm{~s}, 3 \mathrm{H}, \mathrm{CH}_{3}\right), 3.37\left(\mathrm{q}, J=7.5 \mathrm{~Hz}, 2 \mathrm{H}, \mathrm{SCH}_{2} \mathrm{CH}_{3}\right), 7.26-7.48(\mathrm{~m}, 5 \mathrm{H}, \mathrm{Ar}-$ $\mathrm{H}), 8.91(\mathrm{~s}, 1 \mathrm{H}, \mathrm{H} 6-$ pyrimidine $) ;{ }^{13} \mathrm{C}$ NMR (DMSO-d $\left.6, \delta \mathrm{ppm}\right): 13.00\left(\mathrm{CH}_{3}\right), 15.00\left(\mathrm{CH}_{3}\right)$, $25.70\left(\mathrm{CH}_{2} \mathrm{~S}\right), 110.10(\mathrm{C} 3 \mathrm{a}), 120.30-138.85$ (6Ar-C), 139.69 (C7a), $151.25(\mathrm{C} 3), 159.25$ (C6); MS m/z (\%): $270\left[\mathrm{M}^{+}\right]$(85). Anal. calcd. for $\mathrm{C}_{14} \mathrm{H}_{14} \mathrm{~N}_{4} \mathrm{~S}: \mathrm{C}, 62.20 ; \mathrm{H}, 5.22 ; \mathrm{N}, 20.72$; S, 11.86. Found: C, 62.23; H, 5.24; N, 20.73; S, 11.81 .

\section{General procedure for the Synthesis of compounds $4-8$}

To a solution of sodium ethoxide ( $0.01 \mathrm{~mol} \mathrm{Na}$ metal in dry ethanol), compound 2 $(0.01 \mathrm{~mol})$ was added, and then the reaction mixture was stirred at room temperature for about $1 \mathrm{~h}$. 2-Chloroethyl methyl ether, chloroacetaldehyde dimethyl-acetal, 2-chloroehanol, 2-(2-chloroethoxy)-ethanol or epichlorohydrine $(0.01 \mathrm{~mol})$ was added and the reaction mixture was stirred at $70^{\circ} \mathrm{C}$ for $3-4 \mathrm{~h}$, respectively. The reaction mixtures were evaporated under reduced pressure and the residue were crystallized using ethanol to give the title compounds $\mathbf{4}-\mathbf{8}$ respectively.

\section{4-(2-Methoxy-ethylsulfanyl)-3-methyl-1-phenyl-1H-pyrazolo[3,4-d]pyrimidine (4)}

Yield $58 \%$, mp. $189-190^{\circ} \mathrm{C}$, IR showed absence of the NH group. ${ }^{1} \mathrm{H}$ NMR (DMSO-d 6 ppm): 2.42 (s, 3H, $\left.\mathrm{CH}_{3}\right), 2.46\left(\mathrm{~s}, 3 \mathrm{H}, \mathrm{OCH}_{3}\right), 3.25\left(\mathrm{~m}, 2 \mathrm{H}, \mathrm{SCH}_{2}\right), 4.53\left(\mathrm{~m}, 2 \mathrm{H}, \mathrm{CH}_{2}-\mathrm{O}\right)$, 7.25-7.47 (m, 5H, Ar-H), 8.90 (s, 1H, H6-pyrimidine); MS m/z (\%): 300 [M $\mathrm{M}^{+}$(45). Anal. calcd. for $\mathrm{C}_{15} \mathrm{H}_{16} \mathrm{~N}_{4} \mathrm{OS}$ : C, 59.98; H, 5.37; $\mathrm{N}, 18.65 ; \mathrm{S}, 10.68$. Found: $\mathrm{C}, 60.00 ; \mathrm{H}, 5.35 ; \mathrm{N}$, $18.68 ; \mathrm{S}, 10.64$.

\section{4-(2,2-Dimethoxy-ethylsulfanyl)-3-methyl-1-phenyl-1H-pyrazolo[3,4-d]pyrimidine (5)}

Yield $81 \%$, mp. $136-137{ }^{\circ} \mathrm{C}$, IR showed absence of the NH group. ${ }^{1} \mathrm{H}$ NMR (DMSO-d $6, \delta$ ppm): $2.42\left(\mathrm{~s}, 3 \mathrm{H}, \mathrm{CH}_{3}\right), 3.32\left(\mathrm{~s}, 6 \mathrm{H}, 2-\mathrm{O}-\mathrm{CH}_{3}\right), 3.83\left(\mathrm{~d}, 2 \mathrm{H}, \mathrm{S}-\mathrm{CH}^{2}\right), 4.50(\mathrm{t}, 1 \mathrm{H}, \mathrm{S}-$ $\left.\mathrm{CH}_{2}-\mathrm{CH}\right), 7.26-7.48$ (m, 5H, Ar-H), 8.91 (s, 1H, H6-pyrimidine); MS m/z (\%): 330 [M $\left.{ }^{+}\right]$ (55). Anal. calcd. for $\mathrm{C}_{16} \mathrm{H}_{18} \mathrm{~N}_{4} \mathrm{O}_{2} \mathrm{~S}: \mathrm{C}, 58.16 ; \mathrm{H}, 5.49 ; \mathrm{N}, 16.96 ; \mathrm{S}, 9.71$. Found: C, 58.19; H, 5.50; N, 16.93; S, 9.73. 


\section{2-(3-Methyl-1-phenyl-1H-pyrazolo[3,4-d]pyrimidin-4-ylsulfanyl)-ethanol (6)}

Yield $61 \%$, mp. $119-121^{\circ} \mathrm{C}$, IR $\left(\mathrm{KBr}, v, \mathrm{~cm}^{-1}\right): 3416(\mathrm{OH}),{ }^{1} \mathrm{H}$ NMR (DMSO-d ${ }_{6}, \delta \mathrm{ppm}$ ): $2.41\left(\mathrm{~s}, 3 \mathrm{H}, \mathrm{CH}_{3}\right), 3.55\left(\mathrm{~d}, 2 \mathrm{H}, \mathrm{S}-\mathrm{CH}_{2}\right), 4.34\left(\mathrm{~m}, 2 \mathrm{H},-\mathrm{CH}_{2}-\mathrm{OH}\right), 5.20$ (br, $1 \mathrm{H}, \mathrm{OH}, \mathrm{D}_{2} \mathrm{O}$ exchangeable), 7.26-7.48 (m, 5H, Ar-H), 8.91 (s, 1H, H6-pyrimidine); MS m/z (\%): 286 $\left[\mathrm{M}^{+}\right]$(60). Anal. calcd. for $\mathrm{C}_{14} \mathrm{H}_{14} \mathrm{~N}_{4} \mathrm{OS}: \mathrm{C}, 58.72 ; \mathrm{H}, 4.93 ; \mathrm{N}, 19.57$; O, 5.59; S, 11.20 . Found: C, 58.70; H, 4.90; N, 19.55; S, 11.25 .

\section{2-[2-(3-Methyl-1-phenyl-1H-pyrazolo[3,4-d]pyrimidin-4-ylsulfanyl)-ethoxy]-ethanol (7)}

Yield 54\%, mp. $189-190^{\circ} \mathrm{C}$, IR (KBr, $\left.v, \mathrm{~cm}^{-1}\right): 3402(\mathrm{OH}),{ }^{1} \mathrm{H}$ NMR (DMSO-d ${ }_{6}, \delta \mathrm{ppm}$ ): $2.42\left(\mathrm{~s}, 3 \mathrm{H}, \mathrm{CH}_{3}\right), 2.95\left(\mathrm{~m}, 2 \mathrm{H}, \mathrm{S}-\mathrm{CH}_{2}\right), 3.55-3.73\left(\mathrm{~m}, 4 \mathrm{H},-\mathrm{CH}_{2}-\mathrm{CH}_{2}-\mathrm{OH}\right), 3.85(\mathrm{~m}$, $\left.4 \mathrm{H}, \mathrm{S}-\mathrm{CH}_{2}-\mathrm{CH}_{2}-\mathrm{O}\right) 5.32\left(\mathrm{br}, 1 \mathrm{H}, \mathrm{OH}, \mathrm{D}_{2} \mathrm{O}\right.$ exchangeable), 7.26-7.48 (m, 5H, Ar- $\left.\mathrm{H}\right)$, 8.90 (s, 1H, H6-pyrimidine); $\mathrm{MS} m / z(\%): 330\left[\mathrm{M}^{+}\right]$(45). Anal. calcd. for $\mathrm{C}_{16} \mathrm{H}_{18} \mathrm{~N}_{4} \mathrm{O}_{2} \mathrm{~S}: \mathrm{C}$, 58.16; H, 5.49; N, 16.96; S, 9.71. Found: C, 62.20; H, 5.25; N, 20.70; S, 11.80.

\section{2-(3-Methyl-1-phenyl-1 H-pyrazolo[3,4-d]pyrimidin-4-ylsulfanyl)-ethane-1,1-diol (8)}

Yield $86 \%$, mp. $198-200^{\circ} \mathrm{C}$, IR $\left(\mathrm{KBr}, v, \mathrm{~cm}^{-1}\right): 3399(\mathrm{OH}),{ }^{1} \mathrm{H}$ NMR (DMSO-d ${ }_{6}, \delta \mathrm{ppm}$ ): $2.41\left(\mathrm{~s}, 3 \mathrm{H}, \mathrm{CH}_{3}\right), 2.68\left(\mathrm{~m}, 1 \mathrm{H}, \mathrm{Ha}, \mathrm{S}-\mathrm{CH}_{2}\right), 3.46\left(\mathrm{~d}, 1 \mathrm{H}, \mathrm{Hb}, \mathrm{S}-\mathrm{CH}_{2}\right), 4.84(\mathrm{~m}, 1 \mathrm{H}, \mathrm{CH}-$ $\mathrm{OH}), 5.11\left(\mathrm{~m}, 2 \mathrm{H}, \mathrm{OH}, \mathrm{D}_{2} \mathrm{O}\right.$ exchangeable), $7.24-7.49(\mathrm{~m}, 5 \mathrm{H}, \mathrm{Ar}-\mathrm{H}), 8.91(\mathrm{~s}, 1 \mathrm{H}, \mathrm{H} 6-$ pyrimidine); $\mathrm{MS} m / z$ (\%): $302\left[\mathrm{M}^{+}\right]$(60). Anal. calcd. for $\mathrm{C}_{14} \mathrm{H}_{14} \mathrm{~N}_{4} \mathrm{O}_{2} \mathrm{~S}: \mathrm{C}, 62.20 ; \mathrm{H}, 5.22$; N, 20.72; S, 11.86. Found: C, 62.25; H, 5.25; N, 20.70; S, 11.80 .

\subsection{Methods used to evaluate the corrosion and inhibition}

\subsubsection{Weight loss measurements}

The carbon steel used in this study had the composition (weight \%) $0.26 \mathrm{C}, 1.35 \mathrm{Mn}, 0.04$ $\mathrm{P}, 0.05 \mathrm{~S}, 0.005 \mathrm{Nb}, 0.02 \mathrm{~V}, 0.03 \mathrm{Ti}$ and the remainder Fe. For weight loss measurements a coupon of carbon steel with dimension of $2 \times 2 \times 0.2 \mathrm{~cm}$ were used. The electrode surface was polished with different grades of emery papers, degreased with acetone, and rinsed with distilled water. Analytical grade hydrochloric acid was used for preparing the corrosive solution.

\subsubsection{Open circuit potential}

The potential of steel electrode was measured against saturated calomel electrode (SCE) in 1.0 $\mathrm{M} \mathrm{HCl}$ solution in the absence and presence of different concentrations of the used inhibitor at $30^{\circ} \mathrm{C}$. All measurements were carried out using a Multi-tester until the steadystate potentials are reached.

\subsubsection{Galvanostatic polarization measurements}

The working electrode was made from carbon steel rod that has the same composition as mentioned in point 2.2.1. The rod was axially embedded in araldite holder to offer an active flat disc shaped surface of an area $1 \mathrm{~cm}^{2}$. Prior to each experiment, the working electrode was polished successively with fine emery paper, rinsed with acetone, washed 
with double distilled water and finally dried before dipping into the electrolytic cell. A platinum wire was used as a counter electrode and a saturated calomel electrode (SCE) as the reference electrode to which all potentials are referred. The electrochemical experiments are performed using radiometer analytical, Volta master (PGZ301, DYNAMIC ELS VOLTAMMETRY).

\section{Results and Discussion}

\subsection{Chemistry}

Thionation of 3-methyl-1-phenyl-1,5-dihydro-pyrazolo[3,4- $d$ ]pyrimidine-4-one 1 [8] with phosphorus pentasulfide in pyridine afforded the corresponding thione derivative 2 in a quantitative yield as key compound for further synthesis. The structure of the latter compound was confirmed on the basis of its elemental analysis and spectral data ( $c f$. Experimental, Scheme 1). In particular, the infrared (IR) spectrum of compound 2 showed absorption band assignable to the $\mathrm{NH}, \mathrm{C}=\mathrm{S}$ as well as the absence of $\mathrm{C}=\mathrm{O}$ group and $\mathrm{MS}$ gave the molecular ion peak at $m / z(\%): 242\left[\mathrm{M}^{+}, 100\right]$. Alkaline treatment of compound 2 with ethyl iodide in the presence of potassium hydroxide gave the corresponding $S$-alkyl derivative 4-ethylsulfanyl-3-methyl-1-phenyl-1H-pyrazolo[3,4- $d]$ pyrimidine (3). The latter compound showed signals at $\delta 1.39$ and 3.37 for the $S$-ethyl group, in ${ }^{1} \mathrm{H}$ NMR spectrum, and signals at $\delta 15.00$ and 25.70 as well as the absence of $\mathrm{C}=\mathrm{S}$ group, in ${ }^{13} \mathrm{C} \mathrm{NMR}$ spectrum, which indicated that the site of attack is on the sulfur and not on the nitrogen. Similarly, treatment of sodium salt of compound $\mathbf{2}$ with 2-chloroethanol, 2-chloroethyl methyl ether, 2-chloroethyl ethyl ether, or 2-chloroacetaldehyde dimethylacetal, it afforded the corresponding $S$-acyclic nucleosides 4-8, respectively (Scheme 1). The IR spectra of compounds $6-8$ revealed the presence of the $\mathrm{OH}$ absorption band. Also, ${ }^{1} \mathrm{H}$ NMR spectra indicated the presence of methoxyethyl, dimethoxyethyl, hydroxyethyl, hydroxymethoxy ethyl and dihydroxyethyl signals, respectively ( $c f$. Experimental). 


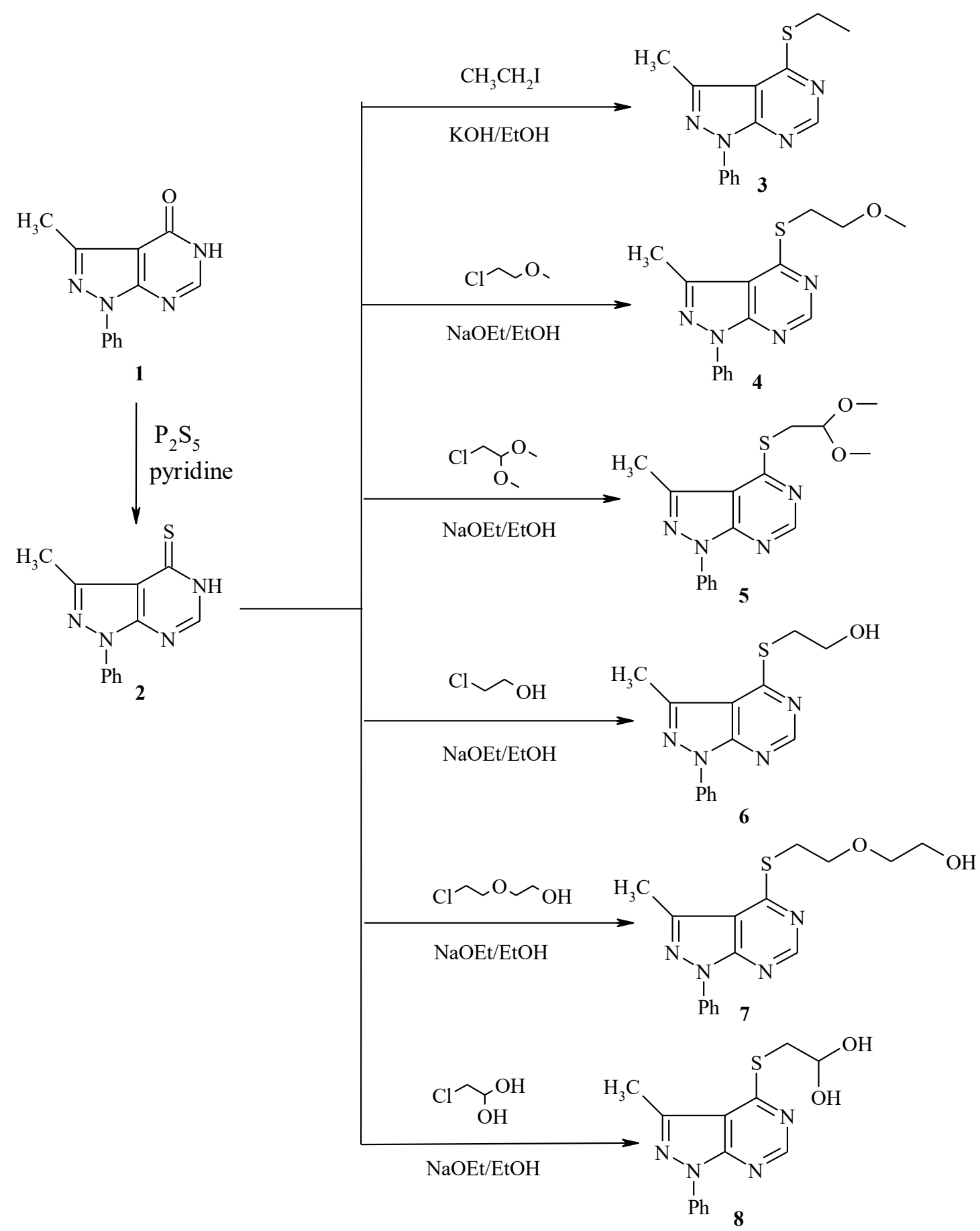

Scheme 1

Figure 1. Chemical structure and Scheme 1 for the synthesized inhibitors (3-8). 


\subsection{Evaluation of the prepared compounds as corrosion inhibitors by weight loss measurements}

\subsubsection{Effect of concentrations on the corrosion inhibition efficiency}

The prepared compounds (3-8) were evaluated as corrosion inhibitors for carbon steel alloy in $1.0 \mathrm{M} \mathrm{HCl}$ solution using average weight loss method. The value of corrosion rate $R_{\text {corr }}$ was calculated from the following equation $[8,25]$ :

$$
R_{\text {corr }}=(\Delta W / S t)
$$

where, $\Delta W$ is the average weight loss of steel coupons in the corrosive solution, $S$ is the total surface area of the specimen, and $t$ is the immersion time. The percentage inhibition efficiency $(\% \mathrm{IE})$ and the surface coverage $(\theta)$, which represents the part of the metal surface covered by the inhibitor molecules, were calculated using the following equations:

$$
\begin{gathered}
\text { I.E. }=\left(R_{\text {free }}-R_{\text {add }} / R_{\text {free }}\right) \times 100 \\
\theta=\left(R_{\text {free }}-R_{\text {add }} / R_{\text {free }}\right)
\end{gathered}
$$

where, $R_{\text {free }}$ and $R_{\text {add }}$ are the weight losses of carbon steel without and with addition of inhibitors, respectively $[8,25]$, while $\theta$ is the part of surface coverage due to adsorption of the inhibitors molecules on the metal surface. It can be assumed that the inhibitor action of these inhibitors due to the blocking of the steel surface by the adsorbed molecules and blocking of the surface area susceptible to corrosion process.

Table 1. Effect of inhibitors concentrations on the corrosion parameters of C-steel in $1.0 \mathrm{M} \mathrm{HCl}$ solution using weight loss measurements at $303 \mathrm{~K}$.

\begin{tabular}{ccccc}
\hline Compound & Concentration, $\mathbf{p p m}$ & $\boldsymbol{R}_{\text {corr, }} \mathbf{~} \mathbf{~} \mathbf{~ c m}^{\mathbf{- 2}} \mathbf{h r}^{-\mathbf{1}}$ & $\mathbf{I . E .} \mathbf{\%}$ & $\boldsymbol{\theta}$ \\
\hline BLANK & 0 & 9 & 0 & 0 \\
\hline \multirow{2}{*}{7} & 100 & 1.1 & 87.7 & 0.877 \\
& 200 & 0.87 & 90.3 & 0.903 \\
& 300 & 0.75 & 91.6 & 0.916 \\
& 400 & 0.64 & 92.9 & 0.929 \\
\hline \multirow{8}{*}{100} & 200 & 1.4 & 84 & 0.84 \\
& 300 & 1.3 & 85.5 & 0.855 \\
& 400 & 1.1 & 87.77 & 0.877 \\
\hline
\end{tabular}


Table 1 (cont.)

\begin{tabular}{|c|c|c|c|c|}
\hline Compound & Concentration, ppm & $R_{\text {corr },}, \mathrm{mg} \mathrm{cm}^{-2} \mathrm{hr}^{-1}$ & I.E. \% & $\theta$ \\
\hline \multirow{4}{*}{6} & 100 & 1.6 & 82 & 0.82 \\
\hline & 200 & 1.4 & 84 & 0.84 \\
\hline & 300 & 1.2 & 86.6 & 0.866 \\
\hline & 400 & 1.1 & 87.7 & 0.877 \\
\hline \multirow{4}{*}{4} & 100 & 2.2 & 75 & 0.75 \\
\hline & 200 & 1.8 & 80 & 0.8 \\
\hline & 300 & 1.6 & 82 & 0.82 \\
\hline & 400 & 1.4 & 84 & 0.84 \\
\hline \multirow{4}{*}{5} & 100 & 2.8 & 68.8 & 0.688 \\
\hline & 200 & 2.7 & 70 & 0.70 \\
\hline & 300 & 2.2 & 75 & 0.75 \\
\hline & 400 & 1.8 & 80 & 0.80 \\
\hline \multirow{4}{*}{3} & 100 & 3.1 & 65 & 0.65 \\
\hline & 200 & 2.9 & 69 & 0.96 \\
\hline & 300 & 2.6 & 72.5 & 0.75 \\
\hline & 400 & 2.2 & 75 & 0.75 \\
\hline
\end{tabular}

The values of percentage of inhibition efficiency and surface coverage $(\theta)$ of the prepared compounds are listed in Table 1. Inspection of this table reveals that, the values of inhibition efficiency increases with increasing concentration of these compounds and the inhibition efficiency decreases in the following order: $\mathbf{C 7}>\mathbf{C 8}>\mathbf{C 6}>\mathbf{C 4}>\mathbf{C 5}>\mathbf{C 3}$. This behavior will be due to functional groups and solubility in aqueous medium.

Figure 2 show weight loss - time curves for carbon steel in $1.0 \mathrm{M} \mathrm{HCl}$ solution in the absence and presence of different concentrations of compound 7 (C7) as an example of the tested inhibitors. Similar curves were obtained for the other compounds. This figure reveals that by increasing the concentrations of this compound, the weight loss of carbon steel samples are decreased. This means that the presence of these compounds retards the corrosion of carbon steel in $1.0 \mathrm{M} \mathrm{HCl}$ solution or in other words, these compounds act as inhibitors. The linear variation of weight loss with time in uninhibited and inhibited $1.0 \mathrm{M}$ $\mathrm{HCl}$ indicates the absence of insoluble surface films during corrosion. In this case, the inhibitors are first adsorbed onto the metal surface and thereafter impede corrosion either by merely blocking the reaction sites (anodic and cathodic) or by altering the mechanism of the anodic and cathodic partial processes [21-24]. 


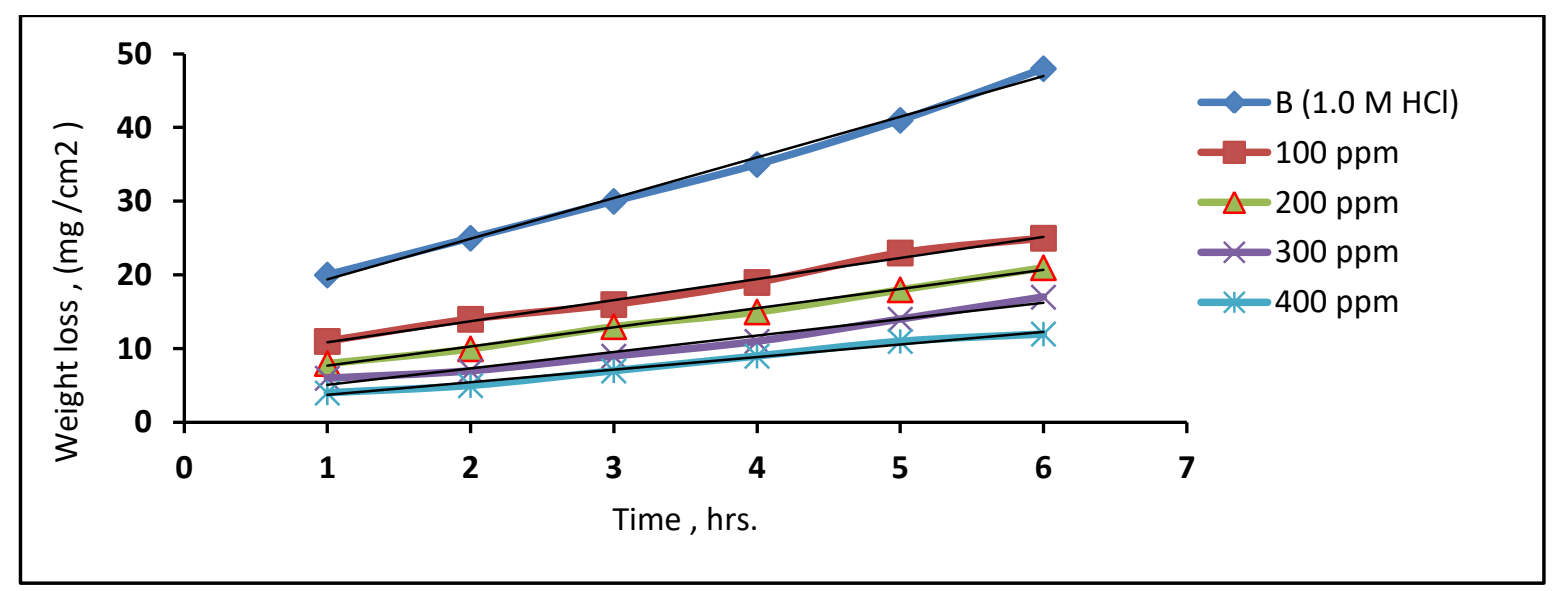

Figure 2. Weight loss of carbon steel as a function in time in $1.0 \mathrm{M} \mathrm{HCl}$ in absence and presence of compound 7 (C7).

\subsubsection{Effect of temperature on the corrosion inhibition efficiency}

To elucidate the mechanism of inhibition and to determine the kinetic parameters of the corrosion process weight loss measurements were performed at 303, 313, 323, $333 \mathrm{~K}$. The effect of temperature on the corrosion inhibition efficiency of carbon steel in the presence of the inhibitor compound 7 is graphically represented in Figure 3.

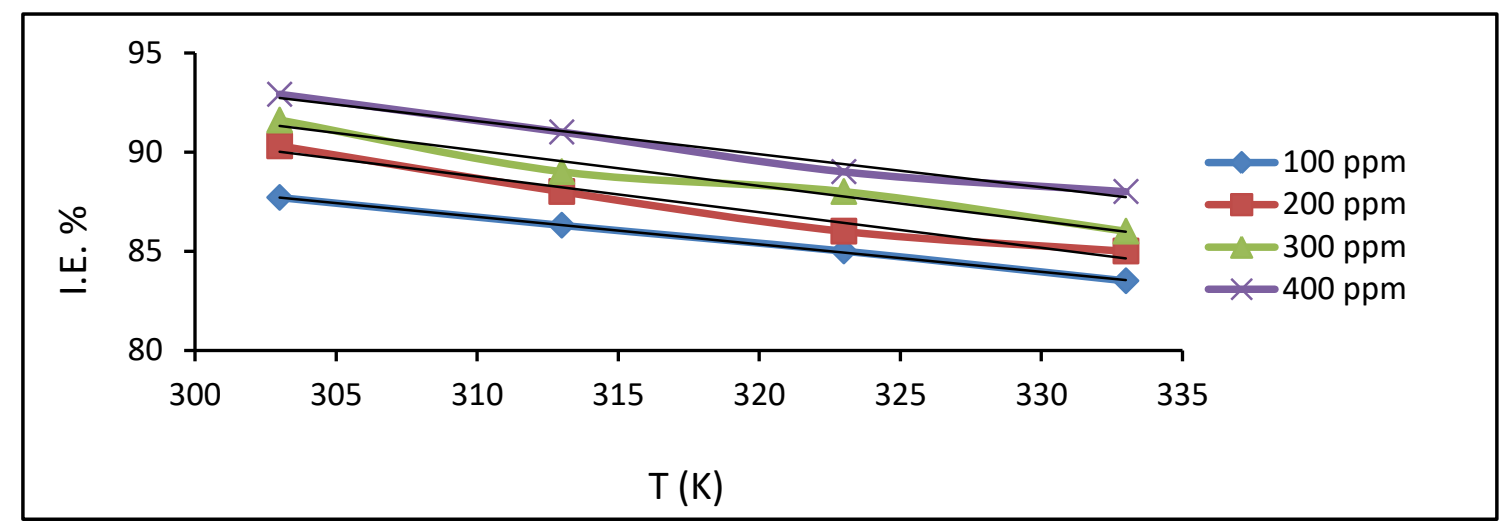

Figure 3. Effect of temperature on \% I.E. for carbon steel in $1.0 \mathrm{M} \mathrm{HCl}$ in the presence of different concentrations of the compound $7(\mathbf{C} 7)$.

The inhibition efficiency decreased with increase in temperature, leading to the conclusion that the protective film of these compounds formed on the steel surface is less stable at higher temperature; which may be due to the desorption of some adsorbed molecules from the surface of the steel at higher temperature due to which greater area of the metal is exposed to the acidic environment. The apparent activation energy $\left(E_{\mathrm{a}}\right)$ of metal corrosion in acid media can be calculated from the Arrhenius equation [20-25]: 


$$
\ln R_{\text {corr. }}=\left(E_{\mathrm{a}} / R T\right)+A
$$

where $E_{\mathrm{a}}$ is the apparent activation energy for the corrosion of carbon steel, $R$ is the universal gas constant, $A$ is Arrhenius preexponential factor and $T$ is the absolute temperature.

Figure 4 depicts the plot of $\log R_{\text {corr. }} v s .1 / T$ and the values of $E_{\mathrm{a}}$ obtained from the slope of the plot are given in Table 2 .

Table 2. Values of activation parameters for carbon steel in $1.0 \mathrm{M} \mathrm{HCl}$ in the absence and presence of different concentrations of the inhibitor compound 7 (C7).

\begin{tabular}{|c|c|c|c|}
\hline $\begin{array}{c}\text { Inhibitor } \\
\text { concentration (ppm) }\end{array}$ & $E_{\mathrm{a}}\left(\mathrm{kJ} \mathrm{mol}^{-1}\right)$ & $\Delta H_{\mathrm{a}}\left(\mathrm{kJ} \mathrm{mol}^{-1}\right)$ & $-\Delta \mathbf{S}_{\mathbf{a}}\left(\mathrm{J} \mathrm{K}^{-1} \mathbf{m o l}^{-1}\right)$ \\
\hline blank & 41.4 & 41.1 & 154.3 \\
\hline $100 \mathrm{ppm}$ & 56 & 56.7 & 149.8 \\
\hline 200 ppm & 60.4 & 61.6 & 146.8 \\
\hline 300 ppm & 63.2 & 64.5 & 142.7 \\
\hline $400 \mathrm{ppm}$ & 65 & 67 & 139.6 \\
\hline
\end{tabular}

The higher value of activation energy $\left(E_{\mathrm{a}}\right)$ in the presence of inhibitor than in its absence is attributed to its physical adsorption, its chemisorption is pronounced in the opposite case [20-25].

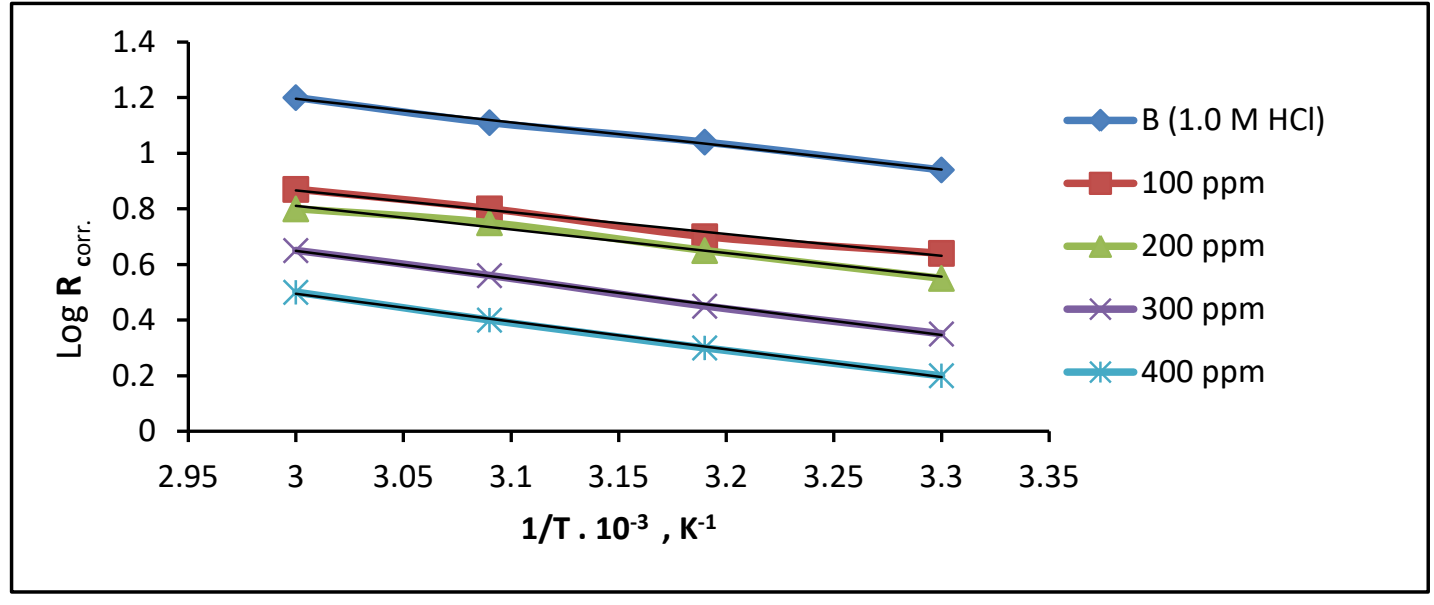

Figure 4. Arrhenius plot for carbon steel in $1.0 \mathrm{M} \mathrm{HCl}$ solution in the absence and presence of different concentrations of the inhibitor compound 7 (C7).

In the present study the higher value of $E_{\mathrm{a}}$ for carbon steel in the presence of inhibitor compared to that in its absence is attributed to its physical adsorption. Szauer and Brand [26] explained that the increase in $E_{a}$ can be attributed to an appreciable decrease in the adsorption of the inhibitor on the steel surface with increase in temperature and a corresponding increase in corrosion rates occurs due to the fact that greater area of metal is 
exposed to acid environment. An alternative form of Arrhenius equation is the transition state equation [20-25]:

$$
R_{\text {corr. }}=(R T / N h) \exp \left(\Delta S_{\mathrm{a}} / R\right) \exp \left(-\Delta H_{\mathrm{a}} / R T\right)
$$

where, $h$ is the Plank's constant, $N$ is the Avogadro's number, $\Delta S_{\mathrm{a}}$ is the entropy of activation, and $\Delta H_{\mathrm{a}}$ is the enthalpy of activation. A plot of $\log (C R / T) v s .1 / T$ gave a straight line as shown in Figure 5 with a slope of $(-\Delta H / 2.303 R)$ and an intercept of $[\log (R / N h)+(\Delta S / R)]$, from which the values of $\Delta H_{\mathrm{a}}$ and $\Delta S_{\mathrm{a}}$ were calculated and listed in Table 2.

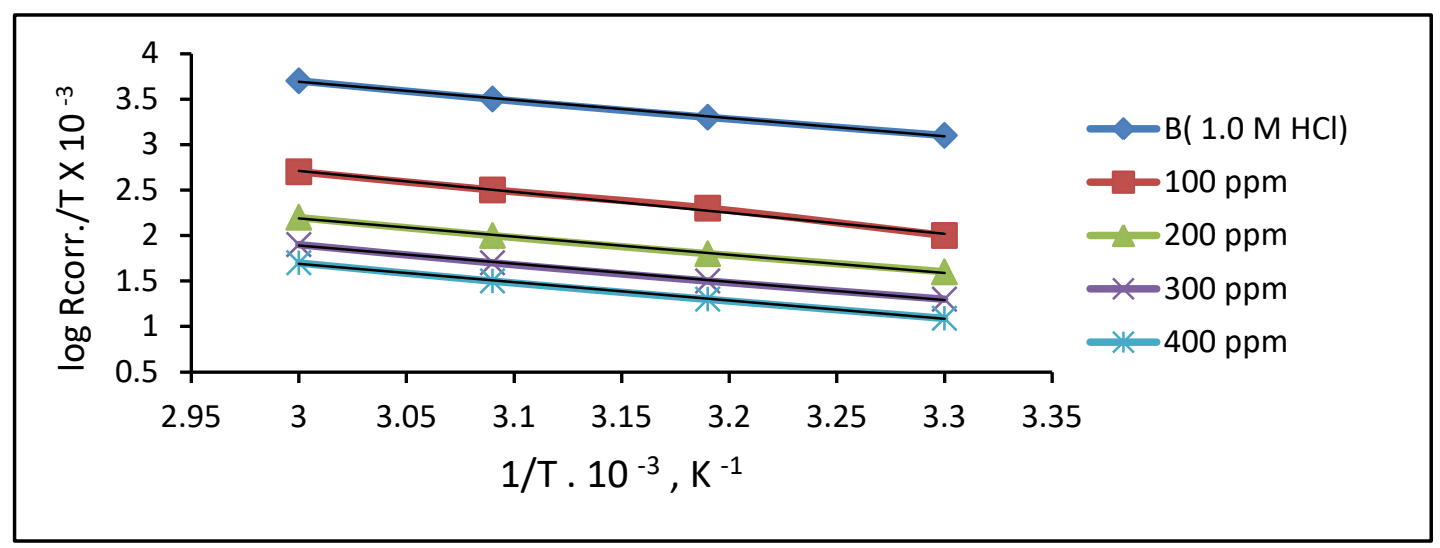

Figure 5. Transition state plot for carbon steel in $1.0 \mathrm{M} \mathrm{HCl}$ solution in the absence and presence of different concentrations of the inhibitor compound 7 (C7).

The positive values of $\Delta H_{\mathrm{a}}$ for corrosion of mild steel in the presence and absence of the inhibitor reflect the endothermic nature of metal dissolution process. The increase in $\Delta H_{\mathrm{a}}$ with increase in the concentration of the inhibitor for mild steel corrosion reveals that decrease in mild steel corrosion rate is mainly controlled by kinetic parameters of activation [19-24]. The entropy of activation values are less negative for inhibited solutions than that for the uninhibited solutions. This suggests that an increase in randomness occurred while moving from reactants to the activated complex $[19,25]$.

\subsection{Open Circuit Potential Measurements}

The potential of carbon steel electrodes immersed in $1.0 \mathrm{M} \mathrm{HCl}$ solution was measured as a function of immersion time in the absence and presence of prepared inhibitor compound 7, as shown in Figure 6. It is clear that the potential of steel electrode immersed in $1.0 \mathrm{M}$ $\mathrm{HCl}$ solution (blank curve) tends towards more negative potential firstly, giving rise to a short step. This behavior was reported by other investigators [23] which represents the breakdown of the pre-immersion air formed oxide film presents on the surface according to the following equation:

$$
\mathrm{Fe}_{2} \mathrm{O}_{3}+6 \mathrm{HCl} \rightarrow 2 \mathrm{FeCl}_{3}+3 \mathrm{H}_{2} \mathrm{O}
$$


After that the potential was shifted again to more noble direction until steady state potential is established. Addition of inhibitor molecules to the aggressive medium produces a negative shift in the open circuit potential due to the retardation of the cathodic reaction.

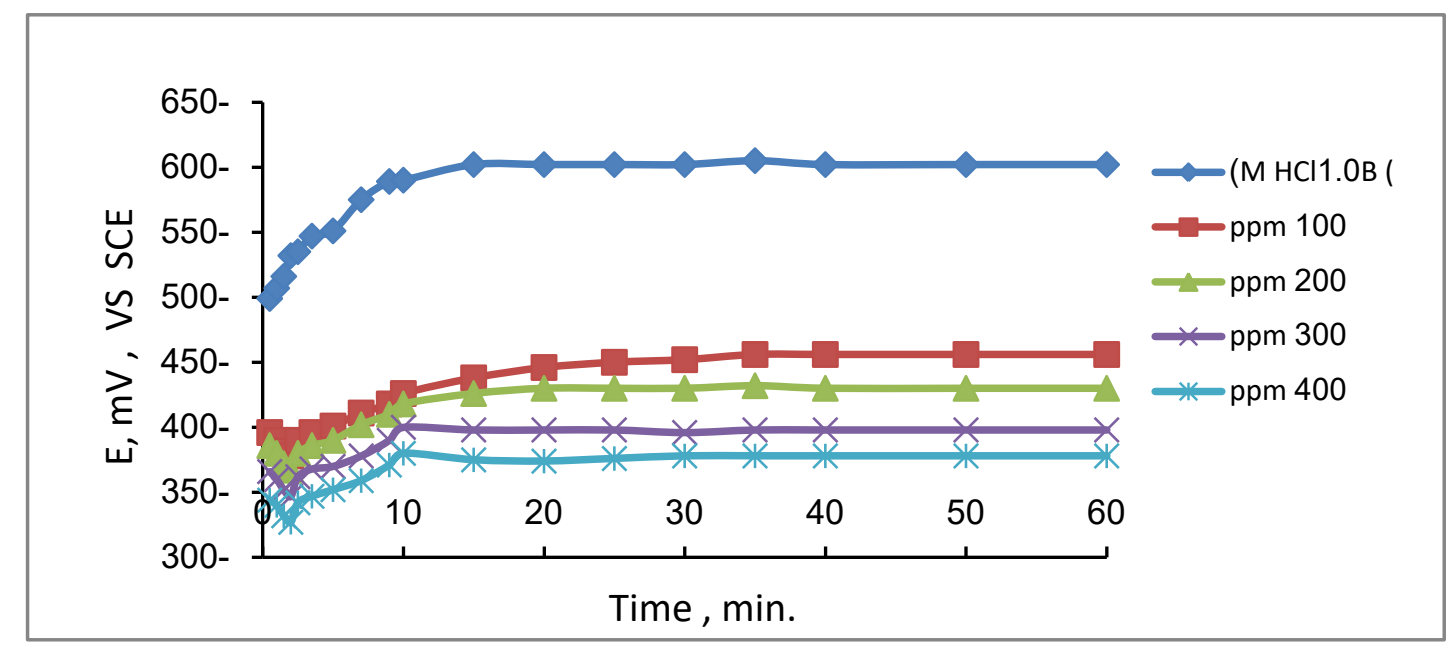

Figure 6. Potential-time curves for carbon steel immersed in $1.0 \mathrm{M} \mathrm{HCl}$ solution in the absence and presence of inhibitor compound 7 (C7).

\subsection{Galvanostatic Polarization Measurements}

Figure 7 illustrates the galvanostatic polarization curves for carbon steel electrode in $1.0 \mathrm{M}$ $\mathrm{HCl}$ solution with and without different concentrations of used inhibitor compound 7. Some electrochemical corrosion parameters such as the values of cathodic $\left(\beta_{c}\right)$ and anodic $\left(\beta_{\mathrm{a}}\right)$ Tafel slopes were determined from the linear region of the polarization curves. The values of corrosion current density $\left(I_{\text {corr }}\right)$ and the corrosion potential $\left(E_{\text {corr. }}\right)$ are listed in Table 3. Inspection of Table 3 it is concluded that the values of anodic $\left(\beta_{\mathrm{a}}\right)$ and cathodic $\left(\beta_{\mathrm{c}}\right)$ Tafel slopes are approximately changed slightly proved that these compounds acted as mixed inhibitors $[24,27]$. The surface area available for anodic dissolution of iron and cathodic hydrogen evolution reaction decreases without affecting the reaction mechanism. The values of $E_{\text {corr. }}$ change slowly to negative values indicating that these inhibitors are of mixed type inhibitors. The values of $I_{\text {corr }}$. decrease and hence the values of IE's increase, indicating the inhibiting effect of these compounds toward the corrosion of carbon steel in $1.0 \mathrm{M} \mathrm{HCl}$ solutions. 


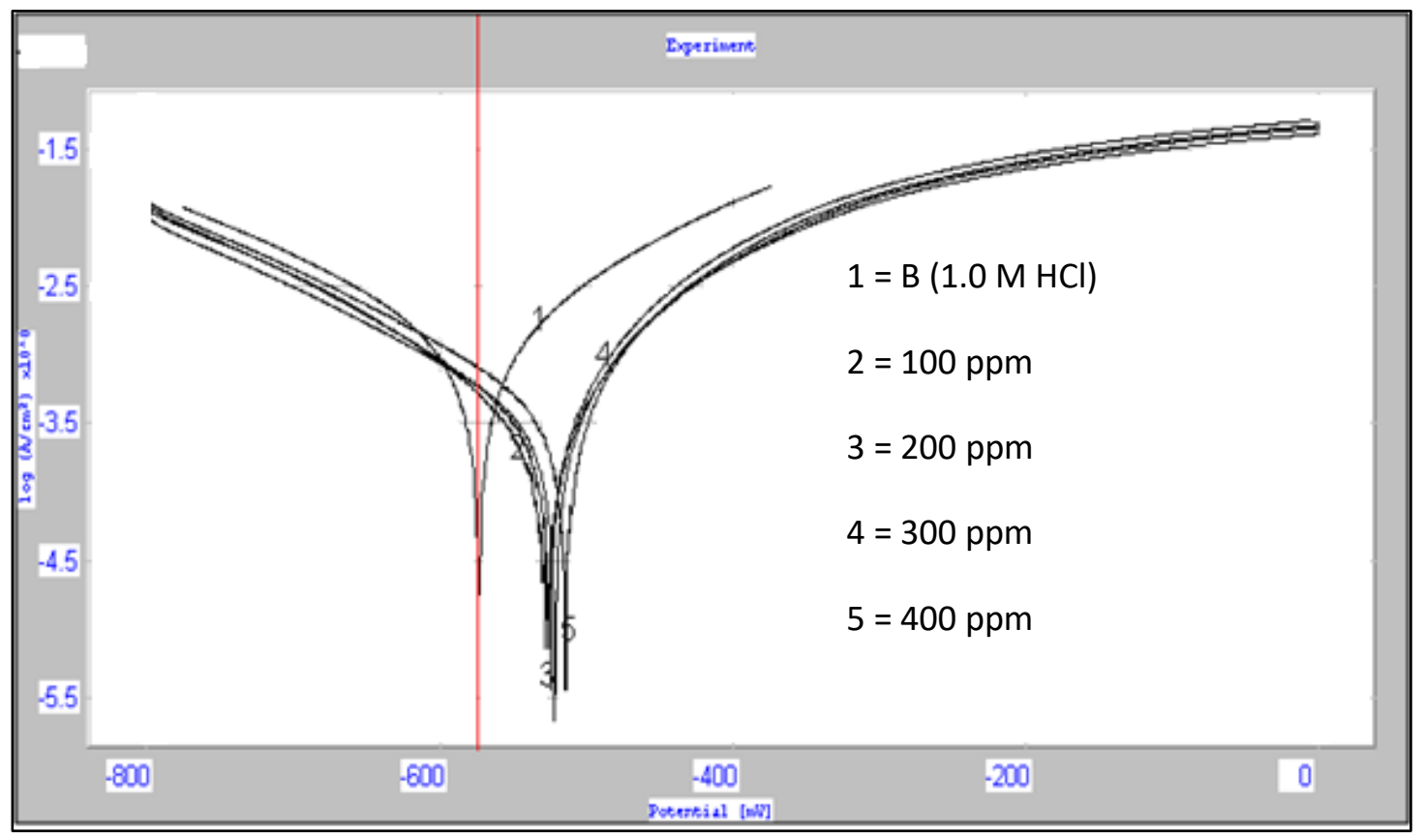

Figure 7. Galvanostatic polarization curves of carbon steel in $1.0 \mathrm{M} \mathrm{HCl}$ solution containing different concentrations of inhibitor compound 7 (C7).

The corrosion inhibition efficiency is given by the following equation [28-33]:

$$
\% \mathrm{IE}=1-\left(I_{\text {inh }} / I_{\text {uninh }}\right) \times 100
$$

where: $I_{\text {uninh }}$ and $I_{\text {inh }}$ are the corrosion current densities in the absence and presence of inhibitor respectively.

Table3 .Electrochemical corrosion parameters obtained from the galvanostatic polarization measurements for carbon steel in 1.0M HCl solution containing different concentrations of inhibitor compound 7.

\begin{tabular}{|c|c|c|c|c|c|c|c|}
\hline Sample & $\begin{array}{c}\text { Conc., } \\
\text { ppm }\end{array}$ & $\begin{array}{c}-E_{\text {corr }} \\
\mathrm{mV} \text { SCE) }\end{array}$ & $\underset{\mathbf{m A ~ c m}}{\mathbf{I}_{\text {corr }}}$ & $\begin{array}{c}\beta_{\mathrm{c}} \\
\mathbf{m V} \operatorname{dec}^{-1}\end{array}$ & $\begin{array}{c}\beta_{\mathrm{a}} \\
\mathbf{m V} \operatorname{dec}^{-1}\end{array}$ & $\%$ IE & $\boldsymbol{\theta}$ \\
\hline $\begin{array}{c}\text { Blank } \\
1.0 \mathrm{M} \mathrm{HCl}\end{array}$ & - & 585.6 & 1.3 & 210 & 177 & - & - \\
\hline \multirow{4}{*}{$\begin{array}{c}\text { Inhibitor } \\
\text { Compound } 7\end{array}$} & 100 & 509.6 & 0.21 & 169.5 & 98.8 & 83.8 & 0.838 \\
\hline & 200 & 503.2 & 0.18 & 175.6 & 103.4 & 86.1 & 0.861 \\
\hline & 300 & 535.4 & 0.15 & 146.5 & 95.6 & 88.5 & 0.885 \\
\hline & 400 & 523.5 & 0.12 & 157.4 & 102.5 & 90.7 & 0.907 \\
\hline
\end{tabular}




\section{Conclusions}

The following conclusions can be extracted from the previous discussion:

1. New acyclic $S$-nucleosides of pyrazolo[3,4- $d]$ pyrimidine-thione derivatives were prepared in good yield and characterized by FT-IR and ${ }^{1} \mathrm{H}$ NMR analysis.

2. Results indicated that, the tested compounds showed promising corrosion inhibitors.

3. The inhibition efficiency decreases in the following order: $\mathbf{C 7}>\mathbf{C 8}>\mathbf{C 6}>\mathbf{C 4}>\mathbf{C 5}>$ C3. This behavior will be due to functional groups and solubility in aqueous medium.

4. The corrosion inhibition efficiency increases with increasing inhibitor concentrations and decreases with temperature.

5. Increase in $\Delta H_{\mathrm{a}}$ with increase in the concentration of the inhibitor reveals that decrease in carbon steel corrosion rate is mainly controlled by kinetic parameters of activation.

6. The entropy of activation values are less negative for inhibited solutions than that for the uninhibited solutions. This suggests that an increase in randomness occurred while moving from reactants to the activated complex.

7. Addition of inhibitor molecules to the aggressive medium produces a negative shift in the open circuit potential due to the retardation of the cathodic reaction.

8. Galvanostatic polarization measurements reveal that thiones compounds act as mixed type inhibitor.

9. The results were in good agreement to each other's.

\section{References}

1. M. Kasula, R. Samunuri, H. Chakravarty, C. Bal, M. Baba, A.K. Jha and A. Sharon, "Regioselective Synthesis of Pyrazolo[3,4- $d]$ Pyrimidine Based Carbocyclic Nucleosides as Possible Antiviral Agent," Nucleosides Nucleotides Nucleic Acids, 2016, 35, no. 1, 43.

2. A.E. Rashad, A.H. Shamroukh, D.A.A. Osman, S.T. Gaballah, A.I. Hashem, H.S. Ali and F.M.E. Abdel-Megeid, "Synthesis and Anticancer Evaluation of Some Fused Pyrazolopyrimidine and Their S-Acyclic Nucleosides," Pharma Chem., 2015, 7, no. 5, 243.

3. R.A. Earl and L.B. Townsend, "The synthesis of certain pyrazolo [3,4- $d]$ pyrimidine nucleosides related to the nucleoside antibiotics toyocamycin and sangivamycin," $J$. Heterocycl. Chem., 1974, 11, no. 6, 1033.

4. A. E. Rashad, A. H. Shamroukh, M. A. Ali and F. M. Abdel-Motti, Synthesis and antiviral screening of some novel pyridazines and triazolopyridazine nucleosides, Heteroatom Chem., 2007, 18, 274.

5. A.E. Rashad, A.H. Shamroukh, R.E. Abdel-Megeid, A. Mostafa, M.A. Ali and K. Banert, "A Facile Synthesis and Anti-Avian Influenza Virus (H5N1) Screening of Some Novel Pyrazolopyrimidine Nucleoside Derivatives," Nucleosides, Nucleotides, 2010, 29, 809 . 
6. A.E. Rashad, A.H. Shamroukh, M.A. El-Hashash, A.F. El-Farargy, N.M. Yousif, M.A. Salama, A. Mostafa and M. El-Shahata, "Synthesis and Anti-Avian Influenza Virus (H5N1) Evaluation of Some Novel Nicotinonitriles and Their N-Acylic Nucleosides," J. Heterocycl. Chem., 2012, 49, 1130.

7. A.H. Shamroukh, M. El-Shahat, J. Drabowicz, M.M. Ali, A.E. Rashad and H.S. Ali, "Anticancer Evaluation of Some Newly Synthesized N-Nicotinonitrile Derivative," Eur. J. Med. Chem., 2013, 69, 521.

8. R.S.A. Hameed, A.H. Shamroukh and M. Abdallah, "Synthesis, Evaluation of Pyrazolo[3,4-d]pyrimidinone Derivatives as Corrosion Inhibitors for Carbon Steel in 1.0 M HCl Acidic Medium," Jokull J., 2016, 66, 24.

9. M. Abdallah, A.M. El-Dafrawy, M. Sobhi, A.H.M. Elwahy and M.R. Shaaban, Int. J. Electrochem. Sci, 2014, 9, 2186.

10. R.S. Abd El-Hameed, H.I. Al Shafey and O.A. Farghaly, "Corrosion of Mild Steel in $\mathrm{NaCl}$ solutions and Effect of Recycled Plastic Waste Inhibitors," Res. Rev. Electrochem., RREC, 2012, 3, no. 2, 41.

11. R.S. Abdel Hameed, H.I. Al Shafey and A.H. Abu-Nawwas, "2-(2,6-dichloranilino) phenyl acetic acid Drugs as Eco-Friendly Corrosion Inhibitors for Mild Steel in $1 \mathrm{M}$ HCl," Int. J. Electrochem. Sci., 2014, 9, 6006.

12. R.S. Abdel Hameed, H.I. Al Shafey, F.A. Ali, Abd El-Aleem, S. Aboul-Magd and M. Salah, "Effect of Expired Drugs as Corrosion Inhibitors for Carbon Steel in $1 \mathrm{M} \mathrm{HCl}$ Solution," Int. J. Pharm. Sci. Rev. Res., 2014, 27, no. 1, 146.

13. M.M. Ibrahim, R.S. Abdel Hameed, A.H. Abu-Nawwas and S.E. Mohamad, "Schiff's bases and their metal complexes as corrosion inhibitors for aluminum alloys in corrosive media," J. Org. Chem., OCAIJ, 2014, 10, no. 7, 271.

14. R.S. Abdel Hameed, H.I. Al-Shafey, Ismail E.A., A.H. Abu-Nawwas and O.E. El Azabawy, "Poly (Oxyethylene)Terphthylamine As Corrosion Inhibitors For Carbon Steel In Methanoic Acid," Int. J. Eng. Res. Appl., 2013, 3, no. 6, 1094.

15. R.S. Abdel Hameed, A.H. Abu-Nawwas and H.A. Shehata, "Nano-composite as Corrosion Inhibitors for Steel Alloys in different corrosive media," Review Article, Adv. Appl. Sci. Res., 2013, 4, no. 3, 126.

16. A. Peter and S.K. Sharma, Int. J. Corros. Scale Inhib., 2017, 6, no. 2, 112. doi: 10.17675/2305-6894-2017-6-2-2

17. R.S. Abdel Hameed, "Expired Drugs as Corrosion Inhibitors for Metals and Alloys," Phys. Chem., An Indian Journal, PCAIJ, 2013, 8, no. 4, 146.

18. H.A. Shehata, H.M. Abdelbary, S.A. Soliman, A.M. Salem, A.M. Atta and R.S. AbdelHameed, "Evaluation of Nonionic Surfactants from Plastic Waste as Corrosion Inhibitors of Carbon steel in 1M HCl," J. Mater. Sci., 2012, 8, no. 7, 289.

19. R.S. Abdel Hameed, O.M. Ismail, F.M. Eissa and R. Ghanem, "New non ionic polymeric surfactants as corrosion inhibitors for the C-Steel alloy in hydrochloric acid corrosive medium," Chem. Sin., 2012, 3, no. 1, 236. 
20. R.S. Abdel Hameed, H.I. Al-Shafey, A.S. Abul Magd and H.A. Shehata, "Pyrazole Derivatives as Corrosion Inhibitor for C- Steel in Hydrochloric Acid Medium," $J$. Mater. Env. Sci., 2012, 3, no. 2, 294.

21. R.S. Abd El-Hameed, "Ranitidine Drugs as Non-Toxic Corrosion Inhibitor for Mild Steel in Hydrochloric Acid Medium," Port. Electrochim. Acta, 2011, 29, no. 4, 273.

22. R.S. Abdel Hameed, "Aminolysis of polyethylene terephthalate waste as corrosion inhibitor for carbon steel in $\mathrm{HCl}$ corrosive medium," Adv. Appl. Sci. Res., 2011, 2, no. 3,483 .

23. R.S. Abdel Hameed, "Recycling of the Used Cooking Oils as Corrosion Inhibitors for Carbon Steel in Hydrochloric acid Corrosive Medium, advances in applied science research," 2016, 7, no. 2, 92.

24. R.S. Abdel Hameed, H.I. Al-Shafey, Ismail E.A. and A.H. Abu-Nawwas, "Expired Voltaren Drugs as Corrosion Inhibitor for Aluminum in Hydrochloric Acid," Int. J. Electrochem. Sci., 2015, 10, 2098.

25. R.S. Abdel Hameed, N.S. Elmetery, N.F. Alshemary and H.A. Shehata, "Recycling of some plastic waste as green corrosion inhibitors for steel in $1 \mathrm{M}$ phosphoric acid," Mater. Sci. J., 2016, 14, no. 11, 417.

26. T. Szauer and A. Brandt, Electrochim. Acta, 1981, 26, 1253.

27. M. Abdullah, B.A. Al Jahdaly and O.A. Al-Malyo, Int. J. Electrochem Sci., 2015, 10, 2740.

28. Ya.G. Avdeev, D.S. Kuznetsov, M.V. Tyurina, S.V. Oleynik and M.A. Chekulaev, Int. J. Corros. Scale Inhib., 2017, 6, no. 1, 47. doi: 10.17675/2305-6894-2017-6-1-4

29. Ya.G. Avdeev and A.Yu. Luchkin, Int. J. Corros. Scale Inhib., 2013, 2, no. 1, 53. doi: 10.17675/2305-6894-2013-2-1-053-066

30. Ya.G. Avdeev, D.S. Kuznetsov, M.V. Tyurina and M.A. Chekulaev, Int. J. Corros. Scale Inhib., 2015, 4, no. 2, 146. doi: 10.17675/2305-6894-2015-4-1-146-161

31. Ya.G. Avdeev, L.V. Frolova, D.S. Kuznetsov, M.V. Tyurina and M.A. Chekulaev, Int. J. Corros. Scale Inhib., 2016, 5, no. 2, 147. doi: 10.17675/2305-6894-2016-5-2-4

32. R.S. Abdel Hameed, A. El-Zomrawy, M. Abdallah, S.S. Abed El Rehim, H.I. AlShafey and Sh. Nour Edin, Int. J. Corros. Scale Inhib., 2017, 6, no. 2, 196. doi: 10.17675/ 2305-6894-2017-6-2-8

33. R.S. Abdel Hameed and M. Abdallah, "Corrosion inhibition of carbon steel in $1 \mathrm{M}$ Hydrochloric acid using some pyrazolo[3,4-d]pyrimidnone derivatives," Prot. Met. Phys. Chem. Surf., 2017 (accepted). 